\title{
Plant-Microbe Interactions in Alleviating Abiotic Stress-A Mini Review
}

\author{
Michael Prabhu Inbaraj* \\ Department of Chemistry, Manipal University Jaipur, Jaipur, India
}

Crop plants are continuously exposed to various abiotic stresses like drought, salinity, ultraviolet radiation, low and high temperatures, flooding, metal toxicities, nutrient deficiencies which act as limiting factors that hampers plant growth and low agricultural productivity. Climate change and intensive agricultural practices has further aggravated the impact of abiotic stresses leading to a substantial crop loss worldwide. Crop plants have to get acclimatized to various environmental abiotic stress factors. Though genetic engineering is applied to improve plants tolerance to abiotic stresses, these are long-term strategies, and many countries have not accepted them worldwide. Therefore, use of microbes can be an economical and ecofriendly tool to avoid the shortcomings of

OPEN ACCESS

Edited by:

Avishek Banik,

Presidency University, India

Reviewed by:

Avishek Pahari,

Orissa University of Agriculture and

Technology, India

Shalini Tiwari,

Jawaharlal Nehru University, India Tushar Suhas Khare,

Savitribai Phule Pune University, India

*Correspondence:

Michael Prabhu Inbaraj michelprabhu.inbaraj

@jaipur.manipal.edu

Specialty section:

This article was submitted to Plant-Soil Interactions, a section of the journal

Frontiers in Agronomy

Received: 15 February 2021 Accepted: 21 April 2021 Published: 19 May 2021

Citation:

Inbaraj MP (2021) Plant-Microbe Interactions in Alleviating Abiotic Stress - A Mini Review.

Front. Agron. 3:667903 doi: 10.3389/fagro.2021.667903 other strategies. The microbial community in close proximity to the plant roots is so diverse in nature and can play an important role in mitigating the abiotic stresses. Plantassociated microorganisms, such as endophytes, arbuscular mycorrhizal fungi (AMF), and plant growth-promoting rhizobacteria (PGPR), are well-documented for their role in promoting crop productivity and providing stress tolerance. This mini review highlights and discusses the current knowledge on the role of various microbes and it's tolerance mechanisms which helps the crop plants to mitigate and tolerate varied abiotic stresses.

Keywords: abiotic stress, AMF, endophytes, mitigation, nutrient uptake, PGPR, tolerance mechanism

\section{INTRODUCTION}

Agriculture is one among the most important essential sectors which is of utmost susceptible to global climate changes. The rapid increase in population with unplanned industrialization, intensive agriculture has led to the degradation of natural resources and environmental contamination (Wan et al., 2012). The increase in the incidences of abiotic stresses affecting crop productivity are being witnessed throughout the world. Crop plants are often exposed to various environmental stresses such as drought, soil acidity, salinity, ultraviolet radiation, high light and extreme temperatures, deficiencies and toxicities of mineral nutrients which severely affects the soil productivity and crop production, worldwide. Based on the report by Food and Agriculture Organization (FAO, 2016), the agricultural production has to be increased by about $60 \%$ by 2050 to feed the increasing global population. Moreover, due to the global climate change accompanied with the other abiotic stresses there will be a decline in the production of major cereal crops $(20-45 \%$ in maize yields, $5-50 \%$ in wheat, and $20-30 \%$ in rice) by the year 2100. The adverse impacts on crop productivity are progressing at an exponential rate due to the direct and indirect effects of abiotic stresses. The worldwide drastic climatic changes along with the rapid increase in the global population has become a major threat to Global food security (Lesk et al., 2016). The resilience 
of crops to various abiotic stresses has to be augmented to ensure high crop productivity in challenging environments to meet the demands of growing population (Pereira, 2016).

Oxygen is essential for the existence of aerobic life, but toxic reactive oxygen species (ROS), which include the superoxide anion radical $\left(\mathrm{O}_{2}^{\bullet-}\right)$, hydroxyl radical $\left(\mathrm{OH}^{\bullet}\right)$, and hydrogen peroxide $\left(\mathrm{H}_{2} \mathrm{O}_{2}\right)$, are generated in all aerobic cells during metabolic processes. Injury caused by these ROS is known as oxidative stress, which is one of the major damaging factors to plants exposed to various environmental stresses which causes extensive cellular damage disrupting the photosynthesis and other physiological functions in plants (Mhamdi and Breusegem, 2018). To mitigate the adverse effect of ROS, plants do respond through the release of enzymatic [superoxide dismutase (SOD), catalase (CAT), ascorbate peroxidase (APX), glutathione reductase (GR), and peroxidase (POD)] and non-enzymatic antioxidants (glutathione, carotenoids, and ascorbates) as a protective mechanism (Sharma et al., 2012).

To overcome the adverse effects of abiotic stresses, the application of microbes is an effective, ecofriendly and economically viable method. The nutrition required for the microbial growth is provided by the root exudates which makes the "rhizosphere" microbial population comparatively diverse from that of its surroundings (Burdman et al., 2000). The microbial biome either living inside or in close vicinity to the plants play a vital role in fighting against the various environmental stresses and has substantially impact on plant growth and development (Hayat et al., 2010; Friesen et al., 2011; Bhattacharyya and Jha, 2012; Bulgarelli et al., 2013; Naeem et al., 2018). Thus, the present concise review highlights and discusses the role of microbes as a biological tool for alleviating and enhancing crop growth under environmental stress conditions.

\section{EFFECT OF ABIOTIC STRESSES ON CROPS}

Abiotic stresses like salinity, drought, heavy metals, nutrient deficiency, high and low temperatures remain major contributors of agricultural losses, and cause more damage to the crops (Figure 1). Soils contaminated with various heavy metals has become a serious environmental concern because of its adverse impact on the agricultural lands. Heavy metal contamination has deleterious effects on several plant physiological functions which ultimately decreases crop productivity which results in severe quantity and quality losses (Hashem et al., 2016). The excess accumulation of heavy metals in plant tissues can have adverse effects on the plants directly or indirectly right from germination of seeds, photosynthesis to poor crop yield (Uzu et al., 2009). Rapid increase in the number of various industries and the use of saline water for crop cultivation is yet another major problem which affects the crop production. Salinity stress conditions has become a major issue which leads to poor crop productivity and is alarmingly increasing in arable land all over the world (Yuan et al., 2015). High salinity significantly impacts various physiological and biochemical processes in plants, such as seed germination, seedling establishment, vegetative growth, ionic toxicity, osmotic pressure, and oxidative damage (Zhao et al., 2010; Feng et al., 2014; Guo et al., 2018). Moreover, high salinity is interlinked with drought, yet another major issue, which can be magnified by extreme temperatures (Slama et al., 2015). Drought stress has significant negative impact on the two photosystems; PSI and PSII, in Kentucky bluegrass and fescue (Fu and Huang, 2001) and can be detrimental to enzyme functioning such as ascorbate peroxidase (APX), glutathione reductase (GR), and superoxide dismutase (SOD) (Hoekstra et al., 2001). Tiwari et al. (2016) have reported that two chickpea cultivars grown under drought stress conditions had significant impact on various growth parameters, water status, membrane integrity, osmolyte accumulation, ROS scavenging ability and stress-responsive gene expressions. Cold stress on the other hand, leads to cell and tissue dehydration, cellular water crystallization, reduced membrane conductivity, higher relative electrolyte leakage (REL), decreased weight, lower relative water content (RWC), and ultimately leading to poor crop yield (Browse and Xin, 2001; Pearce, 2001; Jia et al., 2017). Stevia rebaudiana Bertoni grown under cold stress conditions led to a significant decrease in the maximum quantum yield of photosystem II $\left(\mathrm{F}_{\mathrm{v}} / \mathrm{F}_{\mathrm{m}}\right)$, reductions in net photosynthesis $\left(\mathrm{P}_{\mathrm{N}}\right)$, intercellular $\mathrm{CO}_{2}\left(\mathrm{C}_{\mathrm{i}}\right)$, water use efficiency (WUE), and chl $a$, chl $b$, and carotenoids (Hajihashemi et al., 2018).

The increase in global average temperature can have an alarming impact on the crop production worldwide and can change the pattern of agricultural crops distribution (Porter, 2005). High temperature stress can cause severe protein damage, protein synthesis, enzyme inactivation, membrane damage, root growth, uptake of water and nutrients, oxidative damage, and decreased photosynthetic rate (Smertenko et al., 1997; Wahid et al., 2007, Huang et al., 2012; Djanaguiraman et al., 2018). The photosystem II (PSII) is extremely sensitive to high temperature stress wherein it severely damages the oxygenevolving complex (OEC) and denaturation of D1 and D2 proteins (De Las Rivas and Barber, 1997; De Ronde et al., 2004; Camejo et al., 2005). Soybean plants grown in open top chambers which were exposed to elevated ozone or/and UV radiations significantly decreased the seed which was directly associated with changes in the concentrations of flavonoids, abscisic, acid (ABA) and indole-3-acetic acid (IAA) (Mao et al., 2017). Sugar beet plants under UV-B induced stress conditions showed reduced height and significant decrease in fresh and dry weight which was associated with reduced photosynthetic $\mathrm{O}_{2}$ evolution, photosynthetic pigments, chlorophyll fluorescence, and increased malondialdehyde (MDA) content (Rahimzadeh and Razavi, 2019). Cape gooseberry plants showed reduced plant height, leaf area, stem diameter, dry weight, root and reproductive organs, followed by yellowing, epinasty, necrosis and leaf abscission due to hypoxic conditions in the rhizosphere, under water logging stress condition (Aldana et al., 2014). Maize plants grown under waterlogging conditions significantly decreased the leaf area index (LAI), chlorophyll content, photosynthetic rate (Pn), photochemical efficiency (ФPSII), and resulted in an increased MDA content ultimately causing deterioration of the membrane integrity (Ren et al., 2016). Deficiencies of Fe and P in strawberry plants led to a significant 


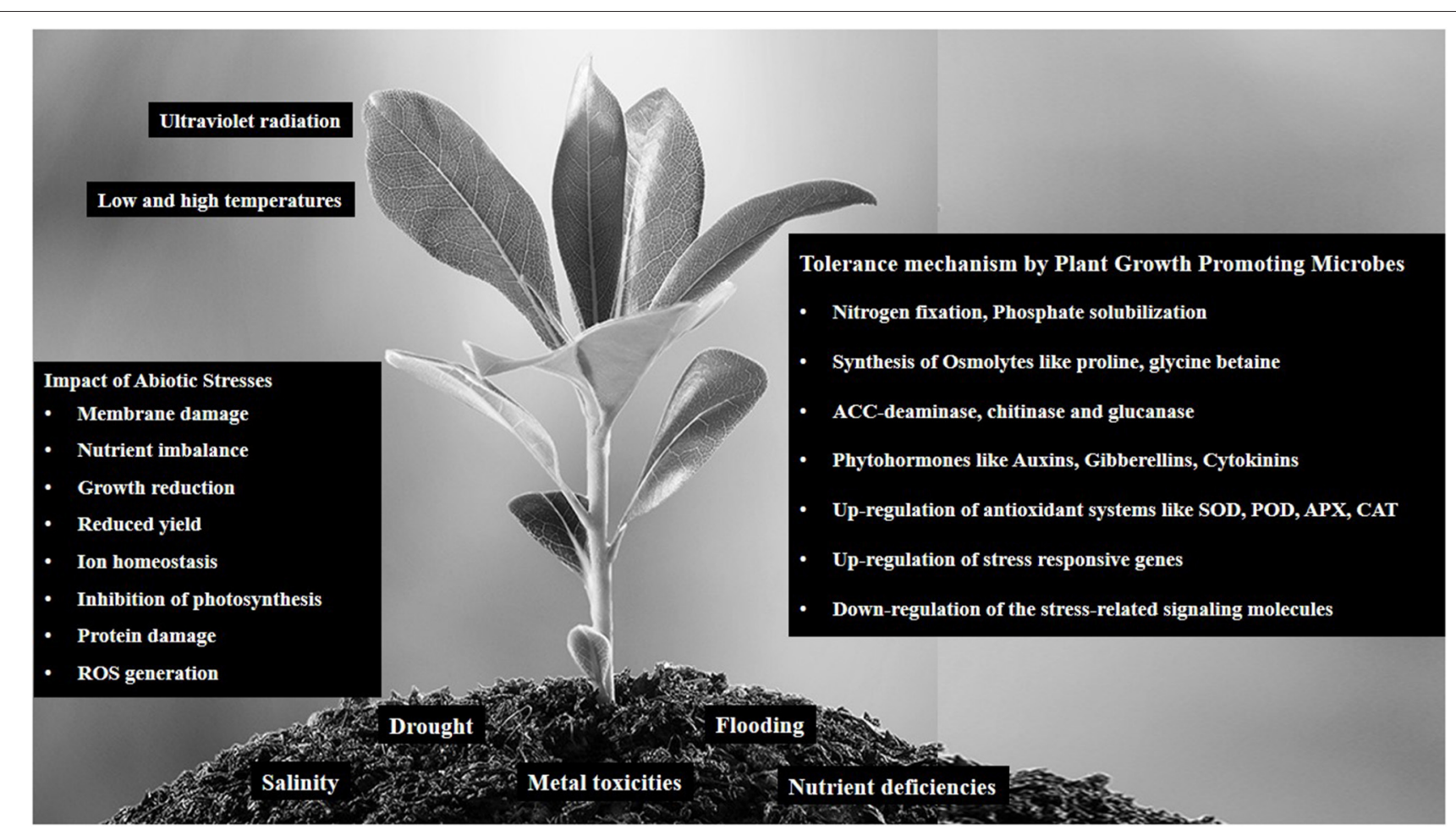

FIGURE 1 | Abiotic stresses, it's impact, and tolerance mechanisms by various Plant Growth Promoting Microbes.

reduction in shoot biomass, leaf size, chlorophyll content, affected the root exudate contents of galactaric acid, malic acid, lysine, proline, sorbitol-6-phosphate, dehydroascorbic acid, galactonate, and ferulic acid (Valentinuzzi et al., 2015). The deficiencies and toxicities of $\mathrm{B}$ and $\mathrm{Zn}$ in soybean plants affected the physiological processes and nutrient concentrations in the different plant tissues has been reported by Pawlowski et al. (2019).

\section{PLANT GROWTH PROMOTING MICROBES}

\section{Endophytes}

Plant endophytes grow inside healthy plant tissues but do not cause any harm or disease to the host plant. Some fungal endophytes promote plant growth despite environmental constraints (Yang et al., 2013). They play a vital role by supporting the host plant nutritionally through increased nitrogen, phosphorus, iron, etc., helps in defending the host plant from environmental stresses and aid in alleviating the stress antagonistic effects (Bacon and White, 2015; White et al., 2017).

The bacterial endophyte Sphingomonas sp. LK11 isolated from the leaves of Tephrosia apollinea alleviated salinity stress in wild-type and Got-3 tomato plants by significantly improving the shoot/root growth through the expression of peroxiredoxin, glutathione S-transferase-, and glutaredoxin-related genes in LK11 genome (Khan et al., 2017). Rice plants inoculated with the root endophytic filamentous fungus, Piriformospora indica, showed significantly enhanced root / shoot lengths, fresh and dry weights, increased photosynthetic pigment contents, which may be attributed to the increased proline accumulation which increased the plants stress tolerance to salinity (Jogawat et al., 2013). The application of encapsulated Metarhizium brunneum strain CB15 endophyte mitigated the nutrient deficiency by significantly enhancing the quantum yields of photosystem II (PSII), water use efficiency, plant biomass production, leaf area, nitrogen, and phosphorus contents in potato plants (Krell et al., 2018). Maize plants grown under drought stress conditions and inoculated with the endophytic fungus Piriformospora indica, a root-colonizing of Sebacinales family, resulted in an increased root fresh and dry weight, leaf area, SPAD value, up-regulation of antioxidants such as catalase and superoxide dismutase. It also led to an increase in the proline content and a decline in the accumulation of malondialdehyde (MDA). The maize plants were able to mitigate the induced drought stress through upregulation of drought-related genes $D R E B 2 A, C B L 1, A N A C 072$, and RD29A (Xu et al., 2017).

Wheat plants infected with six endophytic fungi enhanced the efficiency of PSII, increased $\mathrm{F}_{\mathrm{v}} / \mathrm{F}_{\mathrm{m}}$ values, increased plants height, seed weight, and seed germination rates under heat and drought stress conditions (Hubbard et al., 2014). The japonica rice plants inoculated with the fungal endophyte, Paecilomyces formosus LWL1, significantly improved plant growth attributes, such as plant height, fresh weight, dry weight, and chlorophyll content, increased protein content, grown under heat stress conditions. $P$. formosus LWL1 mitigated the heat stress in rice plants by downregulation of the stress-related signaling molecules, abscisic acid 
(ABA) and jasmonic acid (JA) (Waqas et al., 2015). Soybean plants infected with endophytic fungi Paecilomyces formosus significantly increased plant biomass and growth parameters, reduced lipid peroxidation, and accumulation of linolenic acid, GR, POX, CAT, and SOD under nickel (Ni) stress. This can be attributed to its phytohormonal synthesis and expression of indole-3-acetamide hydrolase, aldehyde dehydrogenase for indoleacetic acid and geranylgeranyl-diphosphate synthase, ent-kaurene oxidase (P450-4), C13-oxidase (P450-3) for gibberellins synthesis (Bilal et al., 2017). Under water stress conditions, capsicum plants inoculated with endophytic fungi Penicillium resedanum LK6 significantly increased the plant growth and yield parameters, peroxidase, catalase and polyphenol oxidase, capsaicin content which were attributed to the up-regulation of Phenylalanine ammonia-lyase and Capsaicin synthase genes activating the phenylpropanoid biosynthesis (Khan et al., 2014).

\section{Arbuscular Mycorrhizal Fungi (AMF)}

Symbiotic association of AMF helps the host plants to overcome various environmental stress conditions like pathogens, acidity, desiccation, and heavy metal toxicity by enhanced photosynthetic rate, water and nutrient uptake and leaf gas exchange (Zuccaro et al., 2009; Sun et al., 2018). AMF are broadly applied as biofertilizers in agriculture and more than $70 \%$ of the vascular plants can have a symbiotic association with AMF specifically under drought conditions by osmotic adjustment and enhanced antioxidant enzyme activity (Kohl et al., 2016; Wu and Zou, 2017). AMF colonization have the ability to enhance the uptake of macro-nutrients and micro-nutrients in plants leading to increased photosynthetic rate and biomass accumulation (Smith et al., 2003; Nell et al., 2010; Chen et al., 2017).

The cyclamen plants inoculated with AMF Glomus fasciculatum markedly enhanced biomass production, increased antioxidant enzymes activity like SOD, APX, as well as an increase in ascorbic acid and polyphenol contents which made the plants tolerant to heat stress conditions (Maya and Matsubara, 2013). Mathur et al. (2016) have reported that the maize plants colonized with AMF tolerated the high temperature stress by increased PSII active reaction centers, quantum efficiency of PSII, excitation energy trapping, performance index, net photosynthetic rate, and hence protecting the oxygen evolving complex (OEC). The AMF Glomus etunicatum protected the maize plants against low temperature stress conditions through improved water conservation (WC) and water use efficiency (WUE) which could play an indirect role in enhancing nutrient uptake, osmotic adjustment, the capacity of gas exchange and the efficiency of photochemistry of PSII (Zhu et al., 2010). AM fungus, Glomus mosseae alleviated the low temperature stress on tomato plants by reduced malondialdehyde (MDA) content, increased photosynthetic pigments, soluble proteins and antioxidant enzyme activities like SOD, POD, APX, and CAT (Abdel Latef and Chaoxing, 2011). AMF can alleviate the heavy metal stress by any of the following mechanisms as reported earlier: (i) uptake and storing the heavy metals in the vacuoles of the fungi; (ii) adhering heavy metals to siderophores and sequester into the root apoplasm or soil; (iii) catalyse the transport of heavy metals from cytoplasm through transporters at the plasmalemma or tonoplast (Galli et al., 1994; Leyval et al., 1997; Schützendübel and Polle, 2002). Pigeon pea plants inoculated with the AMF Glomus mosseae under saline and cadmium $(\mathrm{Cd})$ combined stress conditions enhanced the uptake of $\mathrm{Cd}$, higher concentrations of stress metabolites (sugars, proteins, free amino acids, proline, and glycine betaine) and accumulation of phytochelatins thus enhancing growth, nutrient status, and yield of the host plant (Garg and Chandel, 2012).

Several reports are available that under drought stress conditions, AMF-host plant symbiotic association alleviated the stress effects by increased osmotic adjustment, proline accumulation, enhanced leaf gas exchange, leaf water relations, stomatal conductance, and transpiration rate (Morte et al., 2000; Kubikova et al., 2001; Mena-Violante et al., 2006; Yooyongwech et al., 2013). Tomato plants inoculated with (AM) fungus Rhizophagus irregularis and the plant growth promoting rhizobacteria (PGPR) Variovorax paradoxus 5C2 alleviated the drought stress by enhanced photosynthetic activity, root hydraulic conductivity, and phosphorylation status (Calvo-Polanco et al., 2016). Sweet basil plants inoculated with AMF Glomus desrticola mitigated the reduction of K, $\mathrm{P}$, and $\mathrm{Ca}$ uptake, improved photosynthetic efficiency, gas exchange, and water use efficiency under saline stress condition (Elhindi et al., 2017). A mycorrhizal consortium of Glomus sp., Sclerocystis sp., and Acaulospora sp., enhanced the salt tolerance of date palm plants grown under saline conditions through improved $\mathrm{Ca} / \mathrm{Na}$ and $\mathrm{K} / \mathrm{Na}$ ratios, enhanced concentrations of photosynthetic pigments and protein content, increased activities of antioxidant enzymes (SOD, CAT, POD, and APX) (AitEl-Mokhtar et al., 2019). Sheng et al. (2011) have reported that the AMF Glomus mosseae inoculation has enhanced the accumulation of soluble sugars, reducing sugars, soluble protein, total organic acids, oxalic acid, fumaric acid, acetic acid, malic acid, and citric acid, subsequently enhancing the up-regulation of osmoregulation process in the host maize plants grown under salinity stress condition. Citrus seedlings inoculated with a mixture of AM fungi (Rhizophagus irregularis and Funneliformis mosseae) inhibited the uptake of $\mathrm{Na}$ or $\mathrm{Cl}$ while favoring the uptake of $\mathrm{P}, \mathrm{K}, \mathrm{Fe}$, and $\mathrm{Cu}$ under saline condition (Navarro et al., 2014). Tomato plants inoculated with Scolecobasidium constrictum alleviated the combined drought and salinity stress condition by enhanced biomass production, leaf water relations, stomatal conductance, and $\mathrm{F}_{\mathrm{v}} / \mathrm{F}_{\mathrm{m}}$ (Duc et al., 2018).

\section{Plant Growth-Promoting Rhizobacteria (PGPR)}

PGPR are microorganisms that successfully colonize plant roots and positively enhance plant growth, after been inoculated on seeds. Rhizosphere is the area surrounding a plant root that is inhabited by a distinctive microbial population which are influenced by root exudates like organic acids, amino acids, proteins, sugar, phenolics, and other secondary metabolites (McNear, 2013). The symbiotic relationship between $\mathrm{N}$-fixing rhizobia and legumes has been extensively studied wherein the legumes provide reduced carbon $(\mathrm{C})$ to the rhizobia and in turn, biologically available $\mathrm{N}$ is provided by the rhizobia to the 
legumes. The legume develops root nodules, to host the rhizobia and the rhizobia changes from rod-shaped cell to branched, N-fixing bacteroid (Oke and Long, 1999).

PGPRs are able to synthesize phytohormones such as IAA, gibberellins, ethylene, abscisic acid and cytokinins that help the plants to become tolerant various abiotic environmental stresses. Inoculation of PGPR helps in increased plant dry biomass, grain production, and flowering, which can be related to increase in root development, further enhancing the water and mineral uptake by the host plant roots (Okon et al., 1998). Certain bacteria such as Azospirillum, Bacillus, Burkholderia, Erwinia, Pseudomonas, Rhizobium, or Serratiaare have been reported as phosphate solubilizing bacteria which helps in increasing the biological nitrogen fixation efficiency, improve the availability of $\mathrm{Fe}$ and $\mathrm{Zn}$, and alter the growth of roots or shoots by production of plant hormones (Kucey et al., 1989; Mehnaz and Lazarovits, 2006). Potassium-solubilizing bacteria/fungi have been isolated from rhizosphere soil of different crops, which cause solubilization of potassium by the production of organic/inorganic acids or polysaccharides (Sindhu et al., 2016). PGPR plays a vital role in plant growth and development under stressful conditions through different mechanisms like fixation of nitrogen, solubilization of phosphorus, zinc solubilization, siderophores production, growth regulators, organic acids, enzymes like ACC-deaminase, chitinase, and glucanase (Glick et al., 2007; Berg, 2009; Hayat et al., 2010; Kamran et al., 2017).

Phytohormones are molecular signals (auxin, cytokinin, gibberellic acid, brassinosteroids, ethylene, abscisic acid, salicylic acid, and jasmonic acid) that play a crucial role in plant growth and development, and are expressed in response to environmental stress factors (Fahad et al., 2015). Many PGPR can produce auxins (Omer et al., 2004), gibberellins (Jha and Saraf, 2015), and cytokinins (Ruzzi and Aroca, 2015) which lead to enhanced plant shoot growth and root exudate production. PGPR has the ability to synthesize indole acetic acid (IAA), an important hormone of auxin class, helps in the regulation of differentiation of vascular tissue, differentiation of adventitious and lateral root, cell division, and shoot growth under drought stress conditions (Goswami et al., 2015). Maize plants inoculated with PGPR ameliorated drought stress by enhancing the abscisic acid (ABA) concentration levels, regulating transcription of drought related gene and root hydraulic conductivity (Jiang et al., 2013). Soybean plants inoculated with Pseudomonas putida H-23 mitigated salinity and drought stress by increased chlorophyll content, enhanced shoot length and biomass, enhanced the abscisic acid and salicylic acid, polyphenol, flavonoids, SOD and 2,2-diphenyl-1-picryl-hydrazyl-hydrate (DPPH) scavenging activity (Kang et al., 2014).

Under salinity stress condition, lettuce seeds inoculated with Azospirillum showed better seed germination and vegetative growth (Barassi et al., 2006). Tolerance to salinity stress has been exhibited by two bacterial strains, Bacillus aryabhattai H19-1 and Bacillus mesonae $\mathrm{H} 20-5$ in tomato plants by enhancing ABA levels, accumulating significant levels of proline, abscisic acid (ABA), and antioxidant enzyme activities which might be attributed by the up-regulation of 9-cisepoxycarotenoid dioxygenase 1 (NCED1) and abscisic acid-response element-binding proteins 1 (AREB1) genes (Yoo et al., 2019). Qiyuan et al. (2016) have reported that the rhizobacterium Variovorax paradoxus 5C-2 mitigated salinity stress in pea plants by the secretion of 1-aminocyclopropane-1carboxylase (ACC) deaminase, which helped in improving water relations, ion homeostasis, reduced ethylene production and photosynthesis. Wheat plants inoculated with Piriformospora indica and Azotobacter chroococcum significantly increased shoot and root biomass, photosynthetic pigment contents, decreased malondialdehyde (MDA) content, increased ascorbate peroxidase (APX) and peroxidase (POD) activity, and alleviated the $\mathrm{Zn}$ deficiency conditions. The enhanced zinc uptake might be one of the major mechanisms to improve the wheat plants to cope with Zn deficiency (Abadi and Sepehri, 2015).

\section{TOLERANCE MECHANISMS BY PLANT-MICROBE INTERACTION}

Endophytes exhibit a symbiotic association residing within the plant for the majority of their life cycle and has the ability to colonize plant's internal tissues by entering into the seed, leaf, stem, and root of a host plant. Endophytes help in nitrogen fixation, secrete phytohormones and nutrient acquisition thus improving plant growth. Plants do produce root exudates which acts as the energy source for endophytic microorganism associated with it (Kandel et al., 2017; Shen et al., 2019). During the early stages of endophytic colonization, the bacterial cells synthesize exopolysaccharides (EPS) which facilitate it's attachment onto the root surface and also protects the bacterial cells from oxidative damage (Meneses et al., 2011). Arbuscular mycorrhizal fungi are soil-borne fungi that can significantly enhance plant nutrient acquisition and tolerant to various abiotic stress conditions. The AMF establishes a symbiotic association with its host plant, regulating the growth and development of plants. The AMF mycelial network extends under the roots of the plant, hence promoting nutrient uptake. The common mycorrhizal network $(\mathrm{CMN})$ has a profound effect on the fungalmediated transport of phosphorus $(\mathrm{P})$ and nitrogen $(\mathrm{N})$ to plants and hence support plant development under stressful environmental conditions (Navarro et al., 2014; Sun et al., 2018).

Through plant-microbe interaction, microbes use various biochemical and molecular mechanisms which help in mitigating the negative impact of various abiotic stress on plant growth and development (Figure 1 and Table 1). Phytohormones like auxins, gibberellins and cytokinins play a major role in changing the root morphology, thus enabling the plants to get adapted and tolerant to various abiotic stresses like salinity, heavy metal, drought and nutrient deficiency. Secretion of auxins such as indole acetic acid (IAA) enhances cell elongation, resulting in enhanced root growth, promotes lateral root development and hence, has a positive effect on water acquisition and nutrient uptake by the plants. Plant growth promoting rhizobacteria (PGPR) helps to mitigate the negative impact of abiotic stress through induced systemic tolerance (IST) which includes: (i) production of phytohormones such as indole-3-acetic acid (IAA), cytokinins and abscisic acid (ABA), (ii) production of antioxidants like 
TABLE 1 | Microbial mediated abiotic stress tolerance.

\begin{tabular}{|c|c|c|c|c|}
\hline Plants & Microbes & Stress & Tolerance mechanism & References \\
\hline Panicum turgidum & $\begin{array}{l}\text { Funneliformis mosseae } \\
\text { Rhizophagus intraradices } \\
\text { Claroideoglomus etunicatum }\end{array}$ & Salinity & $\begin{array}{l}\text { Increased chl a, chl } b \text {, carotenoids, } \\
\text { increased antioxidant enzyme activities } \\
\text { like SOD, POD, CAT, and GR, increased } \\
\text { uptake of essential elements like } \\
\text { phosphorous, potassium, and calcium }\end{array}$ & Hashem et al., 2015 \\
\hline $\begin{array}{l}\text { Cucumis sativus, } \\
\text { cv. Dasher II }\end{array}$ & Arbuscular mycorrhizal fungi & Salinity & $\begin{array}{l}\text { Synthesis of pigments, activity of } \\
\text { antioxidant enzymes, including SOD, } \\
\text { CAT, APX, GR, and ascorbic acid, } \\
\text { accumulation of phenols and proline, } \\
\text { jasmonic acid, salicylic acid, and several } \\
\text { important mineral elements (K, Ca, Mg, } \\
\mathrm{Zn}, \mathrm{Fe}, \mathrm{Mn} \text {, and Cu) were enhanced }\end{array}$ & Hashem et al., 2018 \\
\hline Pisum Sativum L. & $\begin{array}{l}\text { Rhizoglomus intraradices, } \\
\text { Funneliformis mosseae, } \\
\text { Rhizoglomus fasciculatum and } \\
\text { Gigaspora sp. }\end{array}$ & Salinity & $\begin{array}{l}\text { Higher nutrient uptake, accumulation of } \\
\text { compatible osmolytes, and lower } \\
\text { cellular leakage of electrolyte }\end{array}$ & Parihar et al., 2020 \\
\hline $\begin{array}{l}\text { Robinia } \\
\text { pseudoacacia L. }\end{array}$ & $\begin{array}{l}\text { Funneliformis mosseae } \\
\text { Rhizophagus intraradices }\end{array}$ & Lead (Pb) & $\begin{array}{l}\text { Higher gas exchange capacity, } \\
\text { non-photochemistry efficiency, and } \\
\text { photochemistry efficiency, enhanced } \\
\text { superoxide dismutase (SOD), ascorbate } \\
\text { peroxidases (APX), and glutathione } \\
\text { peroxidase (GPX) }\end{array}$ & Yang et al., 2015 \\
\hline $\begin{array}{l}\text { Helianthus annuus } \\
\text { L. }\end{array}$ & $\begin{array}{l}\text { Funneliformis mosseae } \\
\text { Rhizophagus intraradices } \\
\text { Claroideoglomus etunicatum }\end{array}$ & Cadmium (Cd) & $\begin{array}{l}\text { Increase in shoot/root fresh and dry } \\
\text { weight, chl } a \text {, chl } b \text {, carotenoids, } \\
\text { antioxidant enzymes like SOD, POD, } \\
\text { CAT, GPX, and GR, decreased fatty } \\
\text { acid content }\end{array}$ & Abd_allah et al., 2015 \\
\hline Poncirus trifoliata & Glomus versiforme & Iron (Fe) & $\begin{array}{l}\text { Promoted growth and phenolic } \\
\text { synthesis, increase in phenylalanine } \\
\text { ammonia-lyase activity (PAL) enzyme } \\
\text { activity and pal1 gene expression }\end{array}$ & Li et al., 2015 \\
\hline $\begin{array}{l}\text { Nicotiana tabacum } \\
\text { L. cv Petit } \\
\text { Havanna }\end{array}$ & Rhizophagus intraradices & $\begin{array}{l}\text { Phosphorus }(\mathrm{P}) \\
\text { deficiency }\end{array}$ & $\begin{array}{l}\text { Decreased rate of root respiration and } \\
\text { exudation of citrate and malate }\end{array}$ & Del-Saz et al., 2017 \\
\hline $\begin{array}{l}\text { Sorghum bicolor } \\
\text { L. }\end{array}$ & $\begin{array}{l}\text { Glomus intraradices, Glomus } \\
\text { mosseae, Glomus aggregatum, } \\
\text { Glomus etunicatum }\end{array}$ & Iron $(\mathrm{Fe})$ deficiency & $\begin{array}{l}\text { Increase in phytosiderophore, } \\
\text { upregulation of SbDMAS2 } \\
\text { (deoxymugineic acid synthase 2), } \\
\text { SbNAS2 (nicotianamine synthase 2), } \\
\text { and SbYS1 (Fe-phytosiderophore } \\
\text { transporter yellow stripe) in roots, } \\
\text { enhanced S-containing antioxidant } \\
\text { metabolites (Met, Cys, and GSH) as } \\
\text { well as enzymes (CAT, SOD, and GR) }\end{array}$ & Prity et al., 2020 \\
\hline $\begin{array}{l}\text { Cucumis sativus } L \text {. } \\
\text { Cv. Zhongnong } \\
\text { No. } 26\end{array}$ & Rhizophagus irregularis & Low temperature & $\begin{array}{l}\text { Improved phosphorus }(P) \text { uptake, } \\
\text { induced of } P_{i} \text { transporter gene } \\
\text { belonging to the } P h t 1 \text { gene family }\end{array}$ & Ma et al., 2015 \\
\hline
\end{tabular}


TABLE 1 | Continued

\begin{tabular}{|c|c|c|c|c|}
\hline Plants & Microbes & Stress & Tolerance mechanism & References \\
\hline $\begin{array}{l}\text { Solanum } \\
\text { lycopersicum L. } \\
\text { cv. Zongza } 9\end{array}$ & Funneliformis mosseae & Low temperature & $\begin{array}{l}\text { Reduced level of } \mathrm{MDA}, \mathrm{H}_{2} \mathrm{O}_{2} \text {, and } \mathrm{O}_{2}^{--} \text {, } \\
\text { induced activities of antioxidant } \\
\text { enzymes APX, MDHAR, GR, and } \\
\text { DHAR, expression levels of APX, } \\
\text { MDHAR, GR, and DHAR genes }\end{array}$ & Liu et al., 2015 \\
\hline $\begin{array}{l}\text { Solanum } \\
\text { melongena L. }\end{array}$ & $\begin{array}{l}\text { Funneliformis mosseae, } \\
\text { Claroideoglomus etunicatum, } \\
\text { Rhizophagus irregularis, and } \\
\text { Diversispora versiformis }\end{array}$ & Low temperature & $\begin{array}{l}\text { Improved photochemical reactions, } \\
\text { activating antioxidant defense systems, } \\
\text { accumulating protecting molecules, } \\
\text { and reducing membrane damages }\end{array}$ & Pasbani et al., 2020 \\
\hline $\begin{array}{l}\text { Colobanthus } \\
\text { quitensis }\end{array}$ & Fungal endophytes & UV-B Radiation & $\begin{array}{l}\text { Expression of genes associated to } \\
\text { UV-B photoreception, accumulation of } \\
\text { flavonoids }\end{array}$ & Barrera et al., 2020 \\
\hline $\begin{array}{l}\text { Solanum } \\
\text { lycopersicum cv. } \\
\text { ACE } 55\end{array}$ & Fusarium solani & Water & $\begin{array}{l}\text { Increased net } \mathrm{CO}_{2} \text { assimilation rate } \\
\left(\mathrm{P}_{\mathrm{N}}\right) \text {, stomatal conductance }\left(\mathrm{g}_{\mathrm{s}}\right) \text {, leaf } \\
\text { relative water content }(\mathrm{RWC}) \text {, and } \\
\text { maximum potential quantum yield of } \\
\text { PSII, enhanced antioxidant enzyme } \\
\text { activities like } \mathrm{SOD}, \mathrm{POD}, \mathrm{APX} \text {, and CAT, } \\
\text { decreased oxidative membrane } \\
\text { damage }\end{array}$ & $\begin{array}{l}\text { Kavroulakis et al., } \\
2018\end{array}$ \\
\hline Triticum aestivum & $\begin{array}{l}\text { Rhizophagus intraradices } \\
\text { Funneliformis mosseae } \\
\text { Funneliformis geosporum }\end{array}$ & Drought & $\begin{array}{l}\text { Increased RWC, maximum } \\
\text { photochemistry, higher Chl content, } \\
\text { restoration of electron transport in PSII, } \\
\text { higher } \mathrm{PI}_{(\mathrm{abs})}, \mathrm{PSI} \text { photochemistry }\end{array}$ & Mathur et al., 2018 \\
\hline Zea mays L. & Glomus versiforme & Drought & $\begin{array}{l}\text { Improved chlorophyll content, mineral } \\
\text { uptake and assimilation, increased } \\
\text { content of compatible solutes, such as } \\
\text { proline, sugars, and free amino acids, } \\
\text { Up-regulation of the antioxidant system }\end{array}$ & Begum et al., 2019 \\
\hline Cicer arietinum L. & $\begin{array}{l}\text { Bacillus subtilis, Bacillus } \\
\text { thuringiensis and Bacillus } \\
\text { megaterium }\end{array}$ & Drought & $\begin{array}{l}\text { Increased leaf proline content, activities } \\
\text { of antioxidant enzymes (CAT, APOX, } \\
\text { POD, and SOD), significant } \\
\text { accumulation of riboflavin, } \\
\text { L-asparagine, aspartate, glycerol, } \\
\text { nicotinamide, and } \\
\text { 3-hydroxy-3-methyglutarate }\end{array}$ & Khan et al., 2019 \\
\hline $\begin{array}{l}\text { Triticum aestivum } \\
\text { and Zea mays }\end{array}$ & $\begin{array}{l}\text { Bacillus sp. and Enterobacter } \\
\text { sp. }\end{array}$ & Drought & $\begin{array}{l}\text { Production of indole-3-acetic acid (IAA) } \\
\text { and salicylic acid (SA) }\end{array}$ & Jochum et al., 2020 \\
\hline
\end{tabular}

SOD, POD, APX, CAT, GR, and (iii) degradation of the ethylene precursor ACC by bacterial ACC deaminase (Farooq et al., 2009; Porcel et al., 2014). Inoculating plants with PGPR containing 1-aminocyclopropane-1-carboxylate (ACC) deaminase enzyme, can help to mitigate abiotic stresses by regulating the ethylene production by metabolizing ACC (an immediate precursor of ethylene biosynthesis) into alpha-ketobutyrate and ammonia (Saleem et al., 2007). Microbes do have the capability to promote plant growth and development under abiotic stress condition by enhancing the production of low-molecular-weight osmolytes, including glycinebetaine, proline and other amino acids, organic acids, nitrogen fixation, mineral phosphate solubilization and producing key enzymes such as ACC-deaminase, chitinase, and glucanase (Ahmad et al., 2011; Gupta et al., 2013). Microbes have enhanced heavy metal tolerance through transportation across cell membrane, accumulation on cell wall, intra as well as extracellular entrapment, formation of complexes and redox reactions (Nanda et al., 2019). Arbuscular mycorrhizal fungi
(AMF) play an important role in mitigating the abiotic stresses through various mechanisms like increased osmotic adjustment, enhanced accumulation of proline, increased glutathione level, down regulation of stress related genes, enhanced synthesis of jasmonic acid, salicylic acid, several important inorganic nutrients and expression of stress resistance genes to enhance the defense system (Kubikova et al., 2001; Ouziad et al., 2005; Lim and Kim, 2013; Yooyongwech et al., 2013; Hashem et al., 2018).

\section{CONCLUSION}

The various abiotic stresses pose a major threat to world food security by exerting their deleterious effects on the crop growth, physiological and biochemical plant functions, and ultimately affecting the crop yield. Of the various strategies adapted by the plants to tolerate the abiotic stresses, the plant-microbe interactions provide an efficient eco-friendly manner in which the plants can cope up with the adverse 
environmental stress conditions. The microbial consortium present in the root microbiome promotes plant growth by regulating phytohormones synthesize, osmolytes, organic acids, improved nutrition uptake, enhanced antioxidant system, and up-regulation of stress tolerant genes. However, further studies are required at molecular level to understand the exact mechanism of stress tolerance imparted by the various microbial community. Moreover, the search for even more potential stress tolerant microbes and application of those microbial consortia

\section{REFERENCES}

Abadi, V. A. J. M., and Sepehri, M. (2015). Effect of Piriformospora indica and Azotobacter chroococcum on mitigation of zinc deficiency stress in wheat (Triticum aestivum L.). Symbiosis 69, 9-19. doi: 10.1007/s13199-015-0361-z

Abd_allah, E. F., Abeer, H., Alqarawi, A. A., and Alwathnani, H. A. (2015). Alleviation of adverse impact of cadmium stress in sunflower (Helianthus annuus L.) by arbuscular mycorrhizal fungi. Pak. J. Bot. 47, 785-795.

Abdel Latef, A. A., and Chaoxing, H. (2011). Arbuscular mycorrhizal influence on growth, photosynthetic pigments, osmotic adjustment and oxidative stress in tomato plants subjected to low temperature stress. Acta Physiol. Plant. 33, 1217-1225. doi: 10.1007/s11738-010-0650-3

Ahmad, M., Zahir, Z. A., Asghar, H. N., and Asghar, M. (2011). Inducing salt tolerance in mung bean through co-inoculation with rhizobia and plant-growth-promoting rhizobacteria containing 1-aminocyclopropane-1carboxylate deaminase. Can. J. Microbiol. 57, 578-589. doi: 10.1139/w11-044

Ait-El-Mokhtar, M., Laouane, R. B., Anli, M., Boutasknit, A., Wahbi, S., and Meddich, A. (2019). Use of mycorrhizal fungi in improving tolerance of the date palm (Phoenix dactylifera L.) seedlings to salt stress. Sci. Hori. 253, 429-438. doi: 10.1016/j.scienta.2019.04.066

Aldana, F., García, P. N., and Fischer, G. (2014). Effect of waterlogging stress on the growth, development and symptomatology of cape gooseberry (Physalis peruviana L.) plants. Rev. Acad. Colomb. Cienc. 38, 393-400. doi: $10.18257 /$ raccefyn. 114

Bacon, C. W., and White, J. F. (2015). Functions, mechanisms and regulation of endophytic and epiphytic microbial communities of plants. Symbiosis 68, 87-98. doi: 10.1007/s13199-015-0350-2

Barassi, C. A., Ayrault, G., Creus, C. M., Sueldo, R. J., and Sobrero, M. T. (2006). Seed inoculation with Azospirillum mitigates $\mathrm{NaCl}$ effects on lettuce. Scient. Horti. 109, 8-14. doi: 10.1016/j.scienta.2006.02.025

Barrera, A., Hereme, R., Ruiz-Lara, S., Larrondo, L. F., Gunde, P. E., Pollmann, S., et al. (2020). Fungal endophytes enhance the photoprotective mechanisms and photochemical efficiency in the antarctic Colobanthus quitensis (Kunth) Bartl. exposed to UV-B radiation. Front. Ecol. Evol. 8:122. doi: 10.3389/fevo.2020.00122

Begum, N., Ahanger, M. A., Su, Y., Lei, Y., Mustafa, N. S. A., Ahmad, P., et al. (2019). Improved drought tolerance by AMF inoculation in maize (Zea mays) involves physiological and biochemical implications. Plants 8:579. doi: $10.3390 /$ plants 8120579

Berg, G. (2009). Plant microbe interactions promoting plant growth and health: perspectives for controlled use of microorganisms in agriculture. Appl. Microbiol. Biotechnol. 84, 11-18. doi: 10.1007/s00253-009-2092-7

Bhattacharyya, P. N., and Jha, D. K. (2012). Plant growth-promoting rhizobacteria (PGPR): emergence in agriculture. World J. Microbiol. Biotechnol. 28, 1327-1350. doi: 10.1007/s11274-011-0979-9

Bilal, S., Khan, A. L., Shahzad, R., Asaf, S., Kang, S. M., and Lee, I. J. (2017). Endophytic Paecilomyces formosus LHL10 augments Glycinemax L. adaptation to Ni-contamination through affecting endogenous phytohormones and oxidative stress. Front. Plant Sci. 8:870. doi: 10.3389/fpls.2017. 00870

Bilal, S., Shahzad, R., Imran, M., Jan, R., Kim, K. M., and Lee, I. J. (2020). Synergistic association of endophytic fungi enhances Glycine max L. resilience to combined abiotic stresses: Heavy metals, high temperature and drought stress. Indust. Crops. Prod. 2019:111931. doi: 10.1016/j.indcrop.2019.111931 on field conditions has to be extensively researched in the future which will be of prime importance in solving the future food security worldwide.

\section{AUTHOR CONTRIBUTIONS}

The author confirms being the sole contributor of this work and has approved it for publication.

Browse, J., and Xin, Z. (2001). Temperature sensing and cold acclimation. Curr Opin. in Plant Biol. 4, 241-246. doi: 10.1016/S1369-5266(00)00167-9

Bulgarelli, D., Schlaeppi, K., Spaepen, S., van Themaat, E. V. L., and Schulze-Lefert, P. (2013). Structure and functions of the bacterial microbiota of plants. Ann. Rev. Plant Biol. 64, 807-838. doi: 10.1146/annurev-arplant-050312-120106

Burdman, S., Jurkevitch, E., and Okon, Y. (2000). "Recent advances in the use of plant growth promoting rhizobacteria (PGPR) in agriculture," in Microbial Interactions in Agriculture and Forestry, eds N. S. Subba Rao and Y.R. Dommergues. (Enfield, NH: Science Publishers), 229-250.

Calvo-Polanco, M., Sanchez-Romera, B., Aroca, R., Asins, M. J., Declerck, S., Dodd, I. C., et al. (2016). Exploring the use of recombinant inbred lines in combination with beneficial microbial inoculants (AM fungus and PGPR) to improve drought stress tolerance in tomato. Environ. Exp. Bot. 131, 47-57. doi: 10.1016/j.envexpbot.2016.06.015

Camejo, D., Rodríguez, P., Angeles Morales, M., Miguel Dell'Amico, J., Torrecillas, A., and Alarcón, J. J. (2005). High temperature effects on photosynthetic activity of two tomato cultivars with different heat susceptibility. J. Plant Physiol. 162, 281-289. doi: 10.1016/j.jplph.2004.07.014

Chen, S., Zhao, H., Zou, C., Li, Y., Chen, Y., Wang, Z., et al. (2017). Combined inoculation with multiple arbuscular mycorrhizal fungi improves growth, nutrient uptake and photosynthesis in cucumber seedlings. Front. Microbiol. 8, 25-16. doi: 10.3389/fmicb.2017.02516

De Las Rivas, J., and Barber, J. (1997). Structure and thermal stability of photosystem II reaction centers studied by infrared spectroscopy. Biochemistry 36, 8897-8903. doi: 10.1021/bi970684w

De Ronde, J. A., Cress, W. A., Krüger, G. H. J., Strasser, R. J., and Van Staden, J. (2004). Photosynthetic response of transgenic soybean plants, containing an Arabidopsis P5CR gene, during heat and drought stress. J. Plant Physiol. 161, 1211-1224. doi: 10.1016/j.jplph.2004.01.014

Del-Saz, N. F., Romero-Munar, A., Cawthray, G. R., Aroca, R., Baraza, E., Flexas, J., et al. (2017). Arbuscular mycorrhizal fungus colonization in Nicotiana tabacum decreases the rate of both carboxylate exudation and root respiration and increases plant growth under phosphorus limitation. Plant Soil. 416, 97-106. doi: 10.1007/s11104-017-3188-y

Djanaguiraman, M., Boyle, D. L., Welti, R., Jagadish, S. V. K., and Prasad, P. V. V. (2018). Decreased photosynthetic rate under high temperature in wheat is due to lipid desaturation, oxidation, acylation, and damage of organelles. BMC Plant Biol. 18:1263. doi: 10.1186/s12870-018-1263-Z

Duc, N. H., Csintalan, Z., and Posta, K. (2018). Arbuscular mycorrhizal fungi mitigate negative effects of combined drought and heat stress on tomato plants. Plant Physiol. Biochem. 132, 297-307. doi: 10.1016/j.plaphy.2018.09.011

Elhindi, K. M., El-Din, S. A., and Elgorban, A. M. (2017). The impact of arbuscular mycorrhizal fungi in mitigating salt-induced adverse effects in sweet basil (Ocimum basilicum L.). Saudi J. Biol. Sci. 24, 170-179. doi: 10.1016/j.sjbs.2016.02.010

Fahad, S., Hussain, S., Bano, A., Saud, S., Hassan, S., Shan, D., et al. (2015). Potential role of phytohormones and plant growth-promoting rhizobacteria in abiotic stresses: consequences for changing environment. Environ. Sci. Pollut. Res. 22, 4907-4921. doi: 10.1007/s11356-014-3754-2

FAO (2016). Climate Is Changing. Food and Agriculture Must Too. Available online at: http://www.fao.org/3/I5758E/I5758E.pdf (accessed May 18, 2016).

Farooq, M., Wahid, A., Kobayashi, N., and Basra, S. M. A. (2009). Plant drought stress: effects, mechanisms and management. Agron. Sustain. Dev. 29, 185-212. doi: 10.1051/agro:2008021 
Feng, Z. T., Deng, Y. Q., Fan, H., Sun, Q. J., Sui, N., and Wang, B. S. (2014). Effects of $\mathrm{NaCl}$ stress on the growth and photosynthetic characteristics of Ulmus pumila L. seedlings in sand culture. Photosyn 52, 313-320. doi: 10.1007/s11099-014-0032-y

Friesen, M. L., Porter, S. S., Stark, S. C., von Wettberg, E. J., Sachs, J. L., and Martinez-Romero, E. (2011). Microbially mediated plant functional traits. Ann. Rev. Eco. Evol. Sys. 42, 23-46. doi: 10.1146/annurev-ecolsys-102710-145039

$\mathrm{Fu}$, J., and Huang, B. (2001). Involvement of antioxidants and lipid peroxidation in the adaptation of two cool-season grasses to localized drought stress. Environ. Exp. Bot. 45, 105-114. doi: 10.1016/S0098-8472(00)00084-8

Galli, U., Schüepp, H., and Brunold, C. (1994). Heavy metal binding by mycorrhizal fungi. Physiol. Plantarum. 92, 364-368. doi: 10.1111/j.1399-3054.1994.tb05349.x

Garg, N., and Chandel, S. (2012). Role of arbuscular mycorrhizal (AM) fungi on growth, cadmium uptake, osmolyte, and phytochelatin synthesis in Cajanus cajan (L.) Millsp. under $\mathrm{NaCl}$ and $\mathrm{Cd}$ stresses. J. Plant Growth Regul. 31, 292-308. doi: 10.1007/s00344-011-9239-3

Glick, B. R., Cheng, Z., Czarny, J., Cheng, Z., and Duan, J. (2007). Promotion of plant growth by ACC deaminase-producing soil bacteria. Eur. J. Plant Pathol. 119, 329-339. doi: 10.1007/s10658-007-9162-4

Goswami, D., Thakker, J. N., and Dhandhukia, P. C. (2015). Simultaneous detection and quantification of indole-3-acetic acid (IAA) and indole-3-butyric acid (IBA) produced by rhizobacteria from l-tryptophan (Trp) using HPTLC. J. Microbiol. Meth. 110, 7-14. doi: 10.1016/j.mimet.2015.01.001

Guo, J., Li, Y., Han, G., Song, J., and Wang, B. (2018). NaCl markedly improved the reproductive capacity of the euhalophyte Suaeda salsa. Funct. Plant Biol. 45, 350-361. doi: 10.1071/FP17181

Gupta, G., Panwar, J., and Jha, P. N. (2013). Natural occurrence of Pseudomonas aeruginosa: a dominant cultivable diazotrophic endophytic bacterium colonizing Pennisetum glaucum (L.) R. Br. Appl. Soil Ecol. 64, 252-261. doi: 10.1016/j.apsoil.2012.12.016

Hajihashemi, S., Noedoost, F., Geuns, J. M. C., Djalovic, I., and Siddique, K. H. M. (2018). Effect of cold stress on photosynthetic traits, carbohydrates, morphology, and anatomy in nine cultivars of Stevia rebaudiana. Front. Plant Sci. 9:1430. doi: 10.3389/fpls.2018.01430

Hashem, A., Abd Allah, E. F., Alqarawi, A. A., Al Huqail, A. A., Egamberdieva, D., and Wirth, S. (2016). Alleviation of cadmium stress in Solanum lycopersicum L. by arbuscular mycorrhizal fungi via induction of acquired systemic tolerance. Saudi J. Biol. Sci. 23, 272-281. doi: 10.1016/j.sjbs.2015.11.002

Hashem, A., Abd_Allah, E. F., Alqarawi, A. A., Aldubise, A., and Egamberdieva, D. (2015). Arbuscular mycorrhizal fungi enhances salinity tolerance of Panicum turgidum Forssk by altering photosynthetic and antioxidant pathways. J. Plant Inter. 10, 230-242. doi: 10.1080/17429145.2015.1052025

Hashem, A., Alqarawi, A. A., Radhakrishnan, R., Al-Arjani, A. B. F., Aldehaish, H. A., et al. (2018). Arbuscular mycorrhizal fungi regulate the oxidative system, hormones and ionic equilibrium to trigger salt stress tolerance in Cucumis sativus L. Saudi J. Biol. Sci. 25, 1102-1114. doi: 10.1016/j.sjbs.2018.03.009

Hayat, R., Ali, S., Amara, U., Khalid, R., and Ahmed, I. (2010). Soil beneficial bacteria and their role in plant growth promotion: a review. Ann. Microbiol. 60, 579-598. doi: 10.1007/s13213-010-0117-1

Hoekstra, F. A., Golovina, E. A., and Buitink, J. (2001). Mechanisms of plant desiccation tolerance. Trends Plant Sci. 6, 431-438. doi: 10.1016/S1360-1385(01)02052-0

Huang, B., Rachmilevitch, S., and Xu, J. (2012). Root carbon and protein metabolism associated with heat tolerance. J. Exp. Bot. 63, 3455-3465. doi: $10.1093 / \mathrm{jxb} / \mathrm{ers} 003$

Hubbard, M., Germida, J. J., and Vujanovic, V. (2014). Fungal endophytes enhance wheat heat and drought tolerance in terms of grain yield and secondgeneration seed viability. J. Appl. Microbiol. 116, 109-122. doi: 10.1111/jam. 12311

Jha, C. K., and Saraf, M. (2015). Plant growth promoting rhizobacteria (PGPR): a review. J. Agric. Res. Dev. 5, 108-119. doi: 10.13140/RG.2.1.5171.2164

Jia, Y., Zou, D., Wang, J., Sha, H., Liu, H., Inayat, M. A., et al. (2017). Effects of $\gamma$-aminobutyric acid, glutamic acid, and calcium chloride on rice (Oryza sativa L.) under cold stress during the early vegetative stage. J. Plant Growth Regul. 36, 240-253. doi: 10.1007/s00344-016-9634-x

Jiang, S., Zhang, D., Wang, L., Pan, J., Liu, Y., Kong, X., et al. (2013). A maize calcium-dependent protein kinase gene, $\mathrm{ZmCPK} 4$, positively regulated abscisic acid signaling and enhanced drought stress tolerance in transgenic Arabidopsis. Plant Physiol. Biochem. 71, 112-120. doi: 10.1016/j.plaphy.2013.07.004

Jochum, M. D., McWilliams, K. L., Borrego, E. J., Kolomiets, M. V., Niu, G., Pierson, E. A., et al. (2020). Bioprospecting plant growth-promoting rhizobacteria that mitigate drought stress in grasses. Front. Microbiol. 10:2106. doi: $10.3389 /$ fmicb.2019.02106

Jogawat, A., Saha, S., Bakshi, M., Dayaman, V., Kumar, M., Dua, M., et al. (2013). Piriformospora indica rescues growth diminution of rice seedlings during high salt stress. Plant Sig. Behav. 8:e26891. doi: 10.4161/psb.26891

Kamran, S., Shahid, I., Baig, D. N., Rizwan, M., Malik, K. A., and Mehnaz, S. (2017). Contribution of zinc solubilizing bacteria in growth promotion and zinc content of wheat. Front. Microbiol. 8:2593. doi: 10.3389/fmicb.2017.02593

Kandel, S., Joubert, P., and Doty, S. (2017). Bacterial endophyte colonization and distribution within plants. Microorganisms 5:77. doi: 10.3390/microorganisms5040077

Kang, S. M., Radhakrishnan, R., Khan, A. L., Kim, M. J., Park, J. M., Kim, B. R. et al. (2014). Gibberellin secreting rhizobacterium, Pseudomonas putida H-23 modulates the hormonal and stress physiology of soybean to improve the plant growth under saline and drought conditions. Plant Physiol. Biochem. 84, 115-124. doi: 10.1016/j.plaphy.2014.09.001

Kavroulakis, N., Doupis, G., Papadakis, I. E., Ehaliotis, C., and Papadopoulou, K. K. (2018). Tolerance of tomato plants to water stress is improved by the root endophyte Fusarium solani FsK. Rhizosphere 6, 77-85. doi: 10.1016/j.rhisph.2018.04.003

Khan, A. L., Shin, J. H., Jung, H. Y., and Lee, I. J. (2014). Regulations of capsaicin synthesis in Capsicum annuum L. by Penicillium resedanum LK6 during drought conditions. Sci. Horti. 175, 167-173. doi: 10.1016/j.scienta.2014. 06.008

Khan, A. L., Waqas, M., Asaf, S., Kamran, M., Shahzad, R., Bilal, S., et al. (2017). Plant growth-promoting endophyte Sphingomonas sp. LK11 alleviates salinity stress in Solanum pimpinellifolium. Environ. Exp. Bot. 133, 58-69. doi: 10.1016/j.envexpbot.2016.09.009

Khan, N., Bano, A., Rahman, M. A., Guo, J., Kang, Z., and Babar, M. A. (2019). Comparative physiological and metabolic analysis reveals a complex mechanism involved in drought tolerance in Chickpea (Cicer arietinum L.) Induced by PGPR and PGRs. Sci. Rep. 9:2097. doi: 10.1038/s41598-019-38702-8

Kohl, L., Lukasiewicz, C. E., and van der Heijden, M. G. (2016). Establishment and effectiveness of inoculated arbuscular mycorrhizal fungi in agricultural soils. Plant Cell Environ. 39, 136-146. doi: 10.1111/pce.12600

Krell, V., Unger, S., Schoenwandt, D. J., and Patel, A. V. (2018). Endophytic Metarhizium brunneum mitigates nutrient deficits in potato and improves plant productivity and vitality. Fungal Ecol. 34, 43-49. doi: 10.1016/j.funeco.2018.04.002

Kubikova, E., Moore, J. L., Ownlew, B. H., Mullen, M. D., and Augé, R. M. (2001). Mycorrhizal impact on osmotic adjustment in Ocimum basilicum during a lethal drying episode. J. Plant Physiol. 158, 1227-1230. doi: 10.1078/0176-1617-00441

Kucey, R. M. N., Janzen, H. H., and Legett, M. E. (1989). Microbially mediated increase in plant available phosphorus. Adv. Agron. 42, 199-228. doi: 10.1016/S0065-2113(08)60525-8

Lesk, C., Rowhani, P., and Ramankutty, N. (2016). Influence of extreme weather disasters on global crop production. Nature 529, 84-87. doi: 10.1038 /nature 16467

Leyval, C., Turnau, K., and Haselwandter, K. (1997). Effect of heavy metal pollution on mycorrhizal colonization and function: physiological, ecological and applied aspects. Mycorrhiza 7, 139-153. doi: 10.1007/s005720050174

Li, J. F., He, X. H., Li, H., Zheng, W. J., Liu, J. F., and Wang, M. Y. (2015). Arbuscular mycorrhizal fungi increase growth and phenolics synthesis in Poncirus trifoliata under iron deficiency. Sci. Horti. 183, 87-92. doi: 10.1016/j.scienta.2014.12.015

Li, X., Sun, P., Zhang, Y., Jin, C., and Guan, C. (2020). A novel PGPR strain Kocuria rhizophila $\mathrm{Y} 1$ enhances salt stress tolerance in maize by regulating phytohormone levels, nutrient acquisition, redox potential, ion homeostasis, photosynthetic capacity and stress-responsive. Environ. Exp. Bot. 174:104023. doi: $10.1016 /$ j.envexpbot.2020.104023

Lim, J. H., and Kim, S. D. (2013). Induction of drought stress resistance by multifunctional PGPR Bacillus licheniformis K11 in pepper. Plant Pathol. J. 29, 201-208. doi: 10.5423/PPJ.SI.02.2013.0021 
Liu, A., Chen, S., Wang, M., Liu, D., Chang, R., Wang, Z., et al. (2015). Arbuscular mycorrhizal fungus alleviates chilling stress by boosting redox poise and antioxidant potential of tomato seedlings. J. Plant Growth Regul. 35, 109-120. doi: 10.1007/s00344-015-9511-z

Ma, J., Janoušková, M., Li, Y., Yu, X., Yan, Y., Zou, Z., et al. (2015). Impact of arbuscular mycorrhizal fungi (AMF) on cucumber growth and phosphorus uptake under cold stress. Func. Plant Biol. 42, 1158-1167. doi: 10.1071/FP15106

Mao, B., Yin, H., Wang, Y., Zhao, T. H., Tian, R. R., Wang, W., et al. (2017). Combined effects of $\mathrm{O}_{3}$ and UV radiation on secondary metabolites and endogenous hormones of soybean leaves. PLoS ONE. 12:e0183147. doi: 10.1371/journal.pone.0183147

Mathur, S., Sharma, M. P., and Jajoo, A. (2016). Improved photosynthetic efficacy of maize Zea mays plants with Arbuscular mycorrhizal fungi (AMF) under high temperature stress. J. Photochem. Photobiol. B. 180, 149-154. doi: 10.1016/j.jphotobiol.2018.02.002

Mathur, S., Tomar, R. S., and Jajoo, A. (2018). Arbuscular Mycorrhizal fungi (AMF) protects photosynthetic apparatus of wheat under drought stress. Photosyn. Res. 39, 227-238. doi: 10.1007/s11120-018-0538-4

Maya, M. A., and Matsubara, Y. (2013). Influence of arbuscular mycorrhiza on the growth and antioxidative activity in Cyclamen under heat stress. Mycorrhiza 23, 381-390. doi: 10.1007/s00572-013-0477-z

McNear, Jr D. H. (2013). The Rhizosphere - roots, soil and everything in between. Nat. Educ. Knowledge 4:1

Mehnaz, S., and Lazarovits, G. (2006). Inoculation effects of Pseudomonas putida, Gluconacetobacter azotocaptans, and Azospirillum lipoferum on corn plant growth under greenhouse conditions. Microb. Ecol. 51, 326-335. doi: 10.1007/s00248-006-9039-7

Mena-Violante, H. G., Ocampo-Jimenez, O., Dendooven, L., Martinez-Soto, G., Gonzalez-Castafeda, J., Davies, F. T., et al. (2006). Arbuscular mycorrhizal fungi enhance fruit growth and quality of chile ancho Capsicum annuum L. cv San Luis plants exposed to drought. Mycorrhiza 16, 261-267. doi: 10.1007/s00572-006-0043-z

Meneses, C. H. S. G., Rouws, L. F. M., Simoes-Araujo, J. L., Vidal, M. S., and Baldani, J. I. (2011). Exopolysaccharide production is required for biofilm formation and plant colonization by the nitrogen-fixing endophyte Gluconacetobacter diazotrophicus. Mol. Plant Microbe Interact. 24, 1448-1458. doi: 10.1094/MPMI-05-11-0127

Mhamdi, A., and Breusegem, F. V. (2018). Reactive oxygen species in plant development. Primer 145:164376. doi: 10.1242/dev.164376

Morte, A., Lovisolo, C., and Schubert, A. (2000). Effect of drought stress on growth and water relations of the mycorrhizal association Helianthemum almeriense-Terfezia claveryi. Mycorrhiza 10, 115-119. doi: 10.1007/s0057200 00066

Naeem, K., Asghari, B., and Peiman, Z. (2018). Effects of exogenously applied plant growth regulators in combination with PGPR on the physiology and root growth of chickpea (Cicer arietinum) and their role in drought tolerance. J. Plant Inter. 13, 239-247. doi: 10.1080/17429145.2018.14 71527

Nanda, M., Kumar, V., and Sharma, D. K. (2019). Multimetal tolerance mechanisms in bacteria: the resistance strategies acquired by bacteria that can be exploited to "clean-up" heavy metal contaminants from water. Aquat. Toxicol. 212, 1-10. doi: 10.1016/j.aquatox.2019.04.011

Navarro, J. M., Pérez-Tornero, O., and Morte, A. (2014). Alleviation of salt stress in citrus seedlings inoculated with arbuscular mycorrhizal fungi depends on the rootstock salt tolerance. J. Plant Physiol. 171, 76-85. doi: 10.1016/j.jplph.2013.06.006

Nell, M., Wawrosch, C., Steinkellner, S., Vierheilig, H., Kopp, B., and Lössl, A. (2010). Root colonization by symbiotic arbuscular mycorrhizal fungi increases sesquiterpenic acid concentrations in Valeriana officinalis L. Planta Med. 76, 393-398. doi: 10.1055/s-0029-1186180

Oke, V., and Long, S. R. (1999). Bacteroid formation in the Rhizobium-legume symbiosis. Curr. Opin. Microbiol. 2, 641-646. doi: 10.1016/S1369-5274(99)00035-1

Okon, Y., Bloemberg, G. V., and Lugtenberg, B. J. J. (1998). "Biotechnology of biofertilization and phy-tostimulation," in Agricultural Biotechnology, ed A. Altman (New York, NY: Marcel Dekker), 327-349. doi: $10.1201 / 9781420049275 . p t 2 a$
Omer, Z. S., Tombolini, R., Broberg, A., and Gerhardson, B. (2004). Indole-3-acetic acid production by pink-pigmented facultative methylotrophic bacteria. Plant Growth Regul. 43, 93-96. doi: 10.1023/B:GROW.0000038360.09079.ad

Ouziad, F., Hildebrandt, U., Schmelzer, E., and Bothe, H. (2005). Differential gene expressions in arbuscular mycorrhizal-colonized tomato grown under heavy metal stress. J. Plant Physiol. 162, 634-649. doi: 10.1016/j.jplph.2004.09.014

Parihar, M., Rakshit, A., Rana, K., Tiwari, G., and Jatav, S. S. (2020). The effect of arbuscular mycorrhizal fungi inoculation in mitigating salt stress of Pea (Pisum Sativum L.). Commun.Soil Sci. Plant Anal. 2020, 1-15. doi: $10.1080 / 00103624.2020 .1784917$

Pasbani, B., Salimi, A., Aliasgharzad, N., and Hajiboland, R. (2020). Colonization with arbuscular mycorrhizal fungi mitigates cold stress through improvement of antioxidant defense and accumulation of protecting molecules in eggplants. Scien. Horti. 272:109575. doi: 10.1016/j.scienta.2020.109575

Pawlowski, M. L., Helfenstein, J., Frossard, E., and Hartman, G. L. (2019). Boron and zinc deficiencies and toxicities and their interactions with other nutrients in soybean roots, leaves, and seeds. J. Plant Nut. 42:1267782. doi: 10.1080/01904167.2019.1567782

Pearce, R. (2001). Plant freezing and damage. Ann. Bot. 87, 417-424. doi: $10.1006 /$ anbo.2000.1352

Pereira, A. (2016). Plant abiotic stress challenges from the changing environment. Front. Plant Sci. 7:1123. doi: 10.3389/fpls.2016.01123

Porcel, R., Zamarreño, Á. M., García-Mina, J. M., and and Aroca, R. (2014). Involvement of plant endogenous ABA in Bacillus megaterium PGPR activity in tomato plants. BMC Plant Biol. 25, 14-36. doi: 10.1186/1471-2229-14-36

Porter, J. R. (2005). Rising temperatures are likely to reduce crop yields. Nature 436, 174-174. doi: $10.1038 / 436174 b$

Prity, S. A., Sajib, S. A., Das, U., Rahman, M. M., Haider, S. A., and Kabir, A. H. (2020). Arbuscular mycorrhizal fungi mitigate Fe deficiency symptoms in sorghum through phytosiderophore-mediated Fe mobilization and restoration of redox status. Protoplasma 257, 1373-1385. doi: 10.1007/s00709-020-01517-w

Qiyuan, W., Ian, C. D., Andrey, A. B., and Fan, J. (2016). Rhizosphere bacteria containing 1-aminocyclopropane-1-carboxylate deaminase increase growth and photosynthesis of pea plants under salt stress by limiting $\mathrm{Na}^{+}$ accumulation. Funct. Plant Biol. 43, 161-172. doi: 10.1071/FP15200

Rahimzadeh, K. P., and Razavi, S. M. (2019). Physiological and biochemical responses of sugar beet (Beta vulgaris L) to ultraviolet-B radiation. PeerJ. 7:e6790. doi: 10.7717/peerj.6790

Ren, B., Zhang, J., Dong, S., Liu, P., and Zhao, B. (2016). Effects of waterlogging on leaf mesophyll cell ultrastructure and photosynthetic characteristics of summer maize. PLoS ONE 11:e0161424. doi: 10.1371/journal.pone.0161424

Ruzzi, M., and Aroca, R. (2015). Plant growth-promoting rhizobacteria act as biostimulants in horticulture. Sci. Hortic. 196, 124-134. doi: 10.1016/j.scienta.2015.08.042

Saleem, M., Arshad, M., Hussain, S., and Bhatti, A. S. (2007). Perspective of plant growth promoting rhizobacteria (PGPR) containing ACC deaminase in stress agriculture. J. Ind. Microbiol. Biotech. 34, 635-648. doi: 10.1007/s10295-007-0240-6

Schützendübel, A., and Polle, A. (2002). Plant responses to abiotic stresses: heavy metal-induced oxidative stress and protection by mycorrhization. J. Exp. Bot. 53, 1351-1365. doi: 10.1093/jexbot/53.372.1351

Sharma, P., Jha, A. B., Dubey, R. S., and Pessarakli, M. (2012). Reactive oxygen species, oxidative damage, and antioxidative defense mechanism in plants under stressful conditions. J. Bot. 2012, 1-26. doi: 10.1155/2012/217037

Shen, F. T., Yen, J. H., Liao, C. S., Chen, W. C., and Chao, Y. T. (2019). Screening of rice endophytic biofertilizers with fungicide tolerance and plant growth promoting characteristics. Sustainability 11:1133. doi: 10.3390/su11041133

Sheng, M., Tang, M., Zhang, F., and Huang, Y. (2011). Influence of arbuscular mycorrhiza on organic solutes in maize leaves under salt stress. Mycorrhiza 21, 423-430. doi: 10.1007/s00572-010-0353-z

Sindhu, S. S., Parmar, P., Phour, M., and Sehrawat, A. (2016). "Potassiumsolubilizing microorganisms (KSMs) and its effect on plant growth improvement," in Potassium Solubilizing Microorganisms for Sustainable Agriculture, eds V. Meena, B. Maurya, J. Verma, and R. Meena (New Delhi: Springer), 171-185. doi: 10.1007/978-81-322-2776-2_13

Slama, I., Abdelly, C., Bouchereau, A., Flowers, T., and Savoure, A. (2015). Diversity, distribution and roles of osmoprotective compounds 
accumulated in halophytes under abiotic stress. Ann. Bot. 115, 433-447. doi: 10.1093/aob/mcu239

Smertenko, A., Draber, P., Viklicky, V., and Opatrny, Z. (1997). Heat stress affects the organization of microtubules and cell division in Nicotiana tabacum cells. Plant Cell Environ. 20, 1534-1542. doi: 10.1046/j.1365-3040.1997.d01-44.x

Smith, S. E., Smith, F. A., and Jakobsen, I. (2003). Mycorrhizal fungi can dominate phosphate supply to plants irrespective of growth responses. Plant Physiol. 133, 16-20. doi: 10.1104/pp.103.024380

Sun, Z., Song, J., Xin, X., Xie, X., and Zhao, B. (2018). Arbuscular mycorrhizal fungal proteins 14-3-3- are involved in arbuscule formation and responses to abiotic stresses during AM symbiosis. Front. Microbiol. 5, 9-19. doi: 10.3389/fmicb.2018.00091

Tiwari, S., Lata, C., Chauhan, P. S., and Nautiyal, C. S. (2016). Pseudomonas putida attunes morphophysiological, biochemical and molecular responses in Cicer arietinum L. during drought stress and recovery. Plant Physiol. Biochem. 99, 108-117. doi: 10.1016/j.plaphy.2015.11.001

Uzu, G., Sobanska, S., Aliouane, Y., Pradere, P., and Dumat, C. (2009). Study of lead phyto availability for atmospheric industrial micronic and sub-micronic particles in relation with lead speciation. Environ. Pollut. 157, 1178-1185. doi: 10.1016/j.envpol.2008.09.053

Valentinuzzi, F., Pii, Y., Vigani, G., Lehmann, M., Cesco, S., and Mimmo, T. (2015). Phosphorus and iron deficiencies induce a metabolic reprogramming and affect the exudation traits of the woody plant Fragaria ananassa. J. Exp. Bot. 66: 6483-6495. doi: 10.1093/jxb/erv364

Wahid, A., Gelani, S., Ashraf, M., and Foolad, M. (2007). Heat tolerance in plants: an overview. Environ. Exp. Bot. 61, 199-223. doi: 10.1016/j.envexpbot.2007.05.011

Wan, Y., Luo, S., Chen, J., Xiao, X., Chen, L., Zeng, G., et al. (2012). Effect of endophyte-infection on growth parameters and Cd-induced phytotoxicity of Cd-hyperaccumulator Solanum nigrum L. Chemo 89, 743-750. doi: 10.1016/j.chemosphere.2012.07.005

Waqas, M., Khan, A. L., Shahzad, R., Ullah, I., Khan, A.r, R., et al. (2015). Mutualistic fungal endophytes produce phytohormones and organic acids that promote japonica rice plant growth under prolonged heat stress. J. Zhejiang Univ. Sci. B 16, 1011-1018. doi: 10.1631/jzus.B1500081

White, J. F., Kingsley, K. I., Kowalski, K. P., Irizarry, I., Micci, A., and Soares, M. A. (2017). Disease protection and allelopathic interactions of seed transmitted endophytic Pseudomonads of invasive reed grass (Phragmites australis). Plant. Soil. 422, 195-208. doi: 10.1007/s11104-016-3169-6

$\mathrm{Wu}$, Q. S., and Zou, Y. N. (2017). "Arbuscular mycorrhizal fungi and tolerance of drought stress in plants," in Arbuscular Mycorrhizas and Stress Tolerance of Plants, ed Q. S. Wu (Singapore: Springer), 25-41. doi: 10.1007/978-981-10-4115-0_2

Xu, L., Wang, A., Wang, J., Wei, Q., and Zhang, W. (2017). Piriformospora indica confers drought tolerance on Zea mays L. through enhancement of antioxidant activity and expression of drought-related genes. Crop J. 5, 251-258. doi: 10.1016/j.cj.2016.10.002

Yang, T., Chen, Y., Wang, X., and Dai, C. (2013). Plant symbionts: keys to the phytosphere. Symbiosis 59, 1-14. doi: 10.1007/s13199-012-0190-2

Yang, Y., Han, X., Liang, Y., Ghosh, A., Chen, J., and Tang, M. (2015). The combined effects of Arbuscular Mycorrhizal Fungi (AMF) and lead (Pb) stress on $\mathrm{Pb}$ accumulation, plant growth parameters, photosynthesis, and antioxidant enzymes in Robinia pseudoacacia L. PLoS ONE 10:e0145726. doi: 10.1371/journal.pone.0145726

Yoo, S. J., Weon, H. Y., Song, J., and Sang, M. K. (2019). Induced tolerance to salinity stress by halotolerant bacteria Bacillus aryabhattai $\mathrm{H} 19-1$ and B. mesonae H20-5 in tomato plants. J. Microbiol. Biotechnol. 29, 1124-1136. doi: 10.4014/jmb.1904.04026

Yooyongwech, S., Phaukinsang, N., Cha-Um, S., and Supaibulwatana, K. (2013). Arbuscular mycorrhiza improved growth performance in Macadamia tetraphylla L. grown under water deficit stress involves soluble sugar and proline accumulation. Plant Growth Regul. 69, 285-293. doi: 10.1007/s10725-012-9771-6

Yuan, F., Lyu, M. J. A., Leng, B. Y., Zheng, G. Y., Feng, Z. T., Li, P. H., et al. (2015). Comparative transcriptome analysis of developmental stages of the Limonium bicolor leaf generates insights into salt gland differentiation. Plant Cell Environ. 38, 1637-1657. doi: 10.1111/pce.12514

Zhao, K. F., Song, J., Fan, H., Zhou, S., and Zhao, M. (2010). Growth response to ionic and osmotic stress of $\mathrm{NaCl}$ in salt-tolerant and salt-sensitive maize. J. Integr. Plant Biol. 52, 468-475. doi: 10.1111/j.1744-7909.2010. 00947.x

Zhu, X. C., Song, F. B., and Xu, H. W. (2010). Arbuscular mycorrhizae improve low temperature stress in maize via alterations in host water status and photosynthesis. Plant Soil. 331, 129-137. doi: 10.1007/s11104-0090239-Z

Zuccaro, A., Basiewicz, M., Zurawska, M., Biedenkopf, D., and Kogel, K. H. (2009). Karyotype analysis, genome organization, and stable genetic transformation of the root colonizing fungus Piriformospora indica. Fungal Genet. Biol. 46, 543-550. doi: 10.1016/j.fgb.2009.03.009

Conflict of Interest: The author declares that the research was conducted in the absence of any commercial or financial relationships that could be construed as a potential conflict of interest.

Copyright (C) 2021 Inbaraj. This is an open-access article distributed under the terms of the Creative Commons Attribution License (CC BY). The use, distribution or reproduction in other forums is permitted, provided the original author(s) and the copyright owner(s) are credited and that the original publication in this journal is cited, in accordance with accepted academic practice. No use, distribution or reproduction is permitted which does not comply with these terms. 